\title{
Butterflies (Lepidoptera: Papilionoidea) of an urban park in northeastern Brazil
}

\author{
Douglas H. A. Melo ${ }^{1 *}$, Marcelo Duarte ${ }^{2}$, Olaf H. H. Mielke , Robert K. Robbins $^{4}$ \& André V. L. Freitas \\ ${ }^{1}$ Universidade Federal de Pernambuco, Programa de Pós-Graduação em Biologia Animal, Centro de Ciências \\ Biológicas, Cidade Universitária, Av. Prof. Moraes Rego, 1235, 50670-901 Recife, PE, Brasil \\ ${ }^{2}$ Universidade de São Paulo, Museu de Zoologia, Avenida Nazaré 481, Ipiranga, 04263-000, \\ São Paulo, SP, Brasil \\ ${ }^{3}$ Universidade Federal do Paraná, Departamento de Zoologia, Laboratório de Estudos de Lepidoptera \\ Neotropical, Caixa postal 19020, 81531-980 Curitiba, PR, Brasil \\ ${ }^{4}$ Smithsonian Institution, Department of Entomology, PO Box 37012, NHB Stop 105, 20013-7012, \\ Washington, USA \\ ${ }_{5}^{5}$ Universidade Estadual de Campinas, Instituto de Biologia, Departamento de Biologia Animal e Museu de \\ História Natural, Cidade Universitária Zeferino Vaz, Rua Monteiro Lobato 255, Caixa postal 6109, 13083-970, \\ Campinas, SP, Brasil \\ *Corresponding author: Douglas H. A. Melo, e-mail: douglashamelo@gmail.com
}

MELO, D. H. A., DUARTE, M., MIElKE, O. H. H., ROBBINS, R. K., FREITAS, A. V. L. Butterflies (Lepidoptera: Papilionoidea) of an urban park in northeastern Brazil. Biota Neotropica. 19(1): e20180614. http://dx.doi.org/10.1590/1676-0611-BN-2018-0614

\begin{abstract}
Despite being one of the groups most well studied in Brazil, the butterfly fauna of northeastern Brazil, especially north of the mouth of São Francisco River, is poorly known. The aim of this study was to inventory the butterfly fauna in a remnant of Atlantic Forest in the state of Pernambuco as a contribution to understanding the distribution of these insects. The study was carried out in a 384.7 hectares fragment of Parque Estadual Dois Irmãos, in the metropolitan region of Recife. The butterflies were sampled monthly with insect nets from August 2011 to July 2012 and from January to August 2016. Additional records were obtained from two entomological collections and from two previous visits to the area in July 2003 and August 2006. A total of 273 species was sampled in 464 hours, with an additional 15 species recorded from the Entomological Collections, totaling 288 butterfly species recorded. The richest family was Hesperiidae (108 species), followed by Nymphalidae (80), Lycaenidae (43) Riodinidae (37), Pieridae (16) and Papilionidae (4). The fauna was dominated by generalist species with a broad geographical distribution, many of them commonly found on open areas, forest edges and secondary vegetation. Roeberella lencates (Hewitson, 1875) and Pheles atricolor atricolor (Butler, 1871) (Riodinidae) represent new records for northeastern Brazil.
\end{abstract}

Keywords: Atlantic Forest, Conservation, Inventory, northeastern Brazil.

\section{As borboletas (Lepidoptera: Papilionoidea) de um parque urbano do nordeste do Brasil}

Resumo: Apesar de ser um dos grupos mais bem estudados no Brasil, as borboletas da região Nordeste, especialmente ao norte da foz do Rio São Francisco, são ainda pouco conhecidas. O objetivo deste estudo foi realizar um inventário da fauna de borboletas em um fragmento de Floresta Atlântica no estado de Pernambuco, como uma contribuição para compreensão sobre a distribuição desses insetos. O estudo foi realizado em um fragmento de Floresta Atlântica de 384.7 hectares do Parque Estadual Dois Irmãos, localizado na região metropolitana de Recife. As borboletas foram amostradas mensalmente, de agosto de 2011 a julho de 2012 e de janeiro a agosto de 2016, com auxílio de redes entomológicas. Registros adicionais foram obtidos de duas Coleções Entomológicas e de duas coletas prévias em julho de 2003 e agosto de 2006. Um total de 273 espécies foi registrado em 464 horas e 15 espécies adicionais registradas a partir de Coleções Entomológicas, totalizando 288 espécies de borboletas registradas. A família mais rica foi Hesperiidae (108 espécies), seguida por Nymphalidae (80), Lycaenidae (43), Riodinidae (37), Pieridae (16) e Papilionidae (4). A fauna de borboletas foi dominada por espécies generalistas com uma ampla distribuição geográfica, muitas delas encontradas comumente em áreas abertas, bordas de mata e em vegetação secundária. Roeberella lencates (Hewitson, 1875) e Pheles atricolor atricolor (Butler, 1871) (Riodinidae) representam um novo registro para o Nordeste do Brasil.

Palavras-chave: Conservação, Floresta Atlântica, Inventário, Nordeste Brasileiro. 


\section{Introduction}

Although the butterfly fauna of Brazil is relatively well sampled, there is still a "knowledge gap" in northeastern Brazil (Santos et al. 2008). The entire region is relatively under-sampled and poorly known, especially in the highly fragmented forests north of the mouth of São Francisco River (Freitas \& Marini-Filho 2011, Iserhard et al. 2017). This region, which is known as the "Pernambuco Center of Endemism" (Brown Jr. 1977, Santos et al. 2007), is the most endangered sector of the Atlantic Forest, with less than $12 \%$ of the original vegetation remaining (Ribeiro et al. 2009), almost half as fragments smaller than 10 ha (Ranta et al. 1998).

Research on the butterfly fauna in northeastern Brazil started in the 19th century with Bates (1867) and continued in the next century (e.g. D’Almeida 1935, Cardoso 1949, Silva 1967, Kesselring \& Ebert 1982). Research activity on butterflies in the region has recently blossomed, with papers on threatened species (Kerpel et al. 2014, Melo et al. 2014) and the natural history of poorly-known species (Cardoso 2005, Freitas \& Brown Jr. 2005, Nobre \& Schlindwein 2011, 2012, Callaghan \& Nobre 2014, Dolibaina et al. 2014, Nobre \& Robbins 2014). Although several partial lists are now available (e.g. Duarte Jr. et al. 2001, Vasconcelos et al. 2009, Zacca et al. 2011, Zacca \& Bravo 2012, Kerpel et al. 2014), very few comprehensive inventories have been published for northeastern Brazil. Examples of recently published well-sampled lists for the region includes those of Nobre et al. (2008, 2012) and Lima \& Zacca (2014) for areas of semi-arid "Caatinga" and the inventories for an altitudinal and coastal Atlantic Forest (Paluch et al. 2011 and 2016, respectively).

The purpose of the present study was to inventory the butterfly species found in "Parque Estadual Dois Irmãos", a forest fragment in the metropolitan region of Recife, Pernambuco, northeastern Brazil, and to compare the results with those of previous inventories in the same region. These baseline results will also serve as a point of comparison for future inventories as ecological succession proceeds in this park.

\section{Material and Methods}

\section{Study area}

Parque Estadual Dois Irmãos (PEDI) (08 00' 48' S, 34 56' $42.9 " \mathrm{~W})$ is a state park in Recife, Pernambuco, northeastern Brazil (Figure 1). PEDI was created by State Law $n^{\circ} 11.622$ of December 29,1998 with ca. 384.7 ha, and has recently expanded (state decree $\mathrm{n}^{\circ}$ 40.547 of March 28, 2014) with the inclusion of adjacent forest (the "Fazenda Brejo dos Macacos"), now totaling 1,157.72 ha. This coastal Atlantic Forest consists of a mix of successional regenerating stages. The present study was carried out in the 384.7 ha area now called "Mata de Dois Irmãos". This area is the original part of the Park, including a 14 ha zoo. The climate is tropical monsoon (Am of Köppen), hot and humid, with a monthly average temperature of $25.8^{\circ} \mathrm{C}$. Rainfall, with an annual precipitation up to $2,400 \mathrm{~mm}$, is seasonal, with a wet season from March to August and a dry season from September to February (Coutinho et al. 1998, Alvares et al. 2014). The predominant soils are dystrophic red-yellow latosols (Coutinho et al. 1998), and the vegetation is classified as ombrophilic dense lowland forest (Veloso et al. 1991).

\section{Sampling and identification}

Sampling was carried out monthly from August 2011 to July 2012, following the protocol described in Brown Jr. (1972), Brown Jr. \& Freitas (2000) and Iserhard et al. (2013), with four sampling days each month, totaling 48 field trips. In addition, occasional visits were conducted between January and August 2016, totaling 17 additional field trips. The daily sampling period was from 9:00 to 16:00 hours, with a total sampling effort of 455 hours. Sampling was conducted along pre-existing trails (up to 2 linear $\mathrm{km}$ ) covering a variety of habitats by one collector using an insect net (with a handle $1 \mathrm{~m}$ in length). Special attention was devoted to forest edges, water bodies or their banks, rich soil and flower patches, small clearings, and other heterogeneous environments. Areas with notable concentrations of butterflies were observed until no additional species had been recorded for a period of five to ten minutes. Additional data were obtained from two previous visits by AVLF (July 29, 2003 and August 10, 2006, totaling 9 samplings hours) and from material deposited in the Entomological Collection, Biology Department, Universidade Federal Rural de Pernambuco (UFRPE), and the Entomological Collection, Universidade Federal de Pernambuco (UFPE). Specimens were mounted and deposited in the following Brazilian institutions: 1) Universidade Federal de Pernambuco, Recife, PE; 2) Museu de Zoologia, Universidade Estadual de Campinas, Campinas, SP; and 3) Coleção Entomológica Padre Jesus Santiago Moure, UFPR, Curitiba, PR.

The authors identified species using the literature, the museum collections for which they are responsible, and their taxonomic expertise, which is partly based on years of fieldwork in Brazil and other Neotropical countries. The Discussion is based on these same information sources. The nomenclature in Table 1 follows Lamas (2004), but higher taxonomic categories for Nymphalidae were updated from Wahlberg et al. (2009), for Riodinidae from Seraphim et al. (2018) and Hall (2018), for Hesperiidae from Warren et al. (2009). The higher classification of butterflies was updated from Heikkilä et al. (2012). All families were sampled, except for the Hedylidae.

\section{Results}

In total, 288 butterfly species in six families were recorded at PEDI (Table 1). The fieldwork yielded 273 species in 464 sampling hours. An additional 15 species had been previously sampled (vouchers in UFPE and UFRPE, as noted in Table 1). The most species rich family was Hesperiidae with 108 species $(37,5 \%)$, followed by Nymphalidae with 80 (28\%), Lycaenidae with 43 (15\%), Riodinidae with 37 (13\%), Pieridae with 16 (5,5\%) and Papilionidae with 4 (1\%).

A number of unusual riodinid species were found. The species Roeberella lencates (Hewitson, 1875) and Pheles atricolor atricolor (Butler, 1871) were recorded for northeastern Brazil for the first time (Table 1). A single individual of $R$. lencates was captured when resting in a "pitangueira" tree (Eugenia uniflora, Myrtaceae) in an open sunny area known as "Chapéu do Sol". A single individual of $P$. atricolor atricolor was found on a trail along a forest edge. It made short flights followed by landing on a leaf. A third riodinid Eurybia gonzaga Dolibaina, Dias, Mielke \& Casagrande, 2014 is a recently described endemic for Pernambuco. It was observed frequently in PEDI. This species flies near the ground at dusk. It lands on the underside of leaves. 
Butterflies of an urban park in Brazil
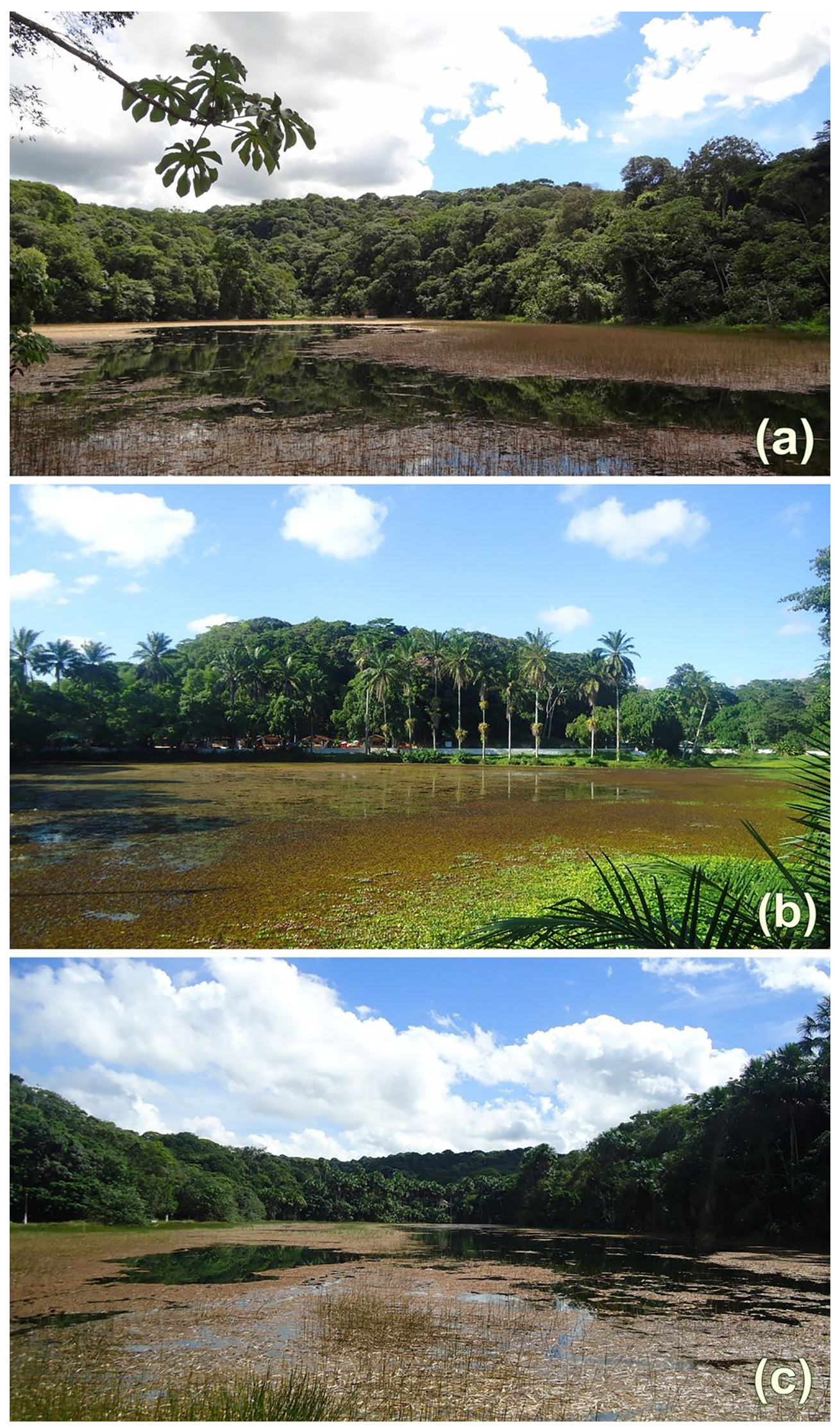

Figure 1. View of the "Parque Estadual Dois Irmãos", Recife, Pernambuco, Brazil, showing the vegetal formation next to the three following weirs: (a) Açude do Prata; (b) Açude do Parque; (c) Açude do Meio. 
Melo, D.H.A. et al.

Table 1. Butterflies (Lepidoptera) from the "Parque Estadual Dois Irmãos", Recife, Pernambuco, Brazil. Number of species are noted within parenthesis for each major taxon. ${ }^{1}$ Data from the UFPE Entomological Collection; ${ }^{2}$ Data from the UFRPE Entomological Collection; ${ }^{3}$ new record for northeastern Brazil.

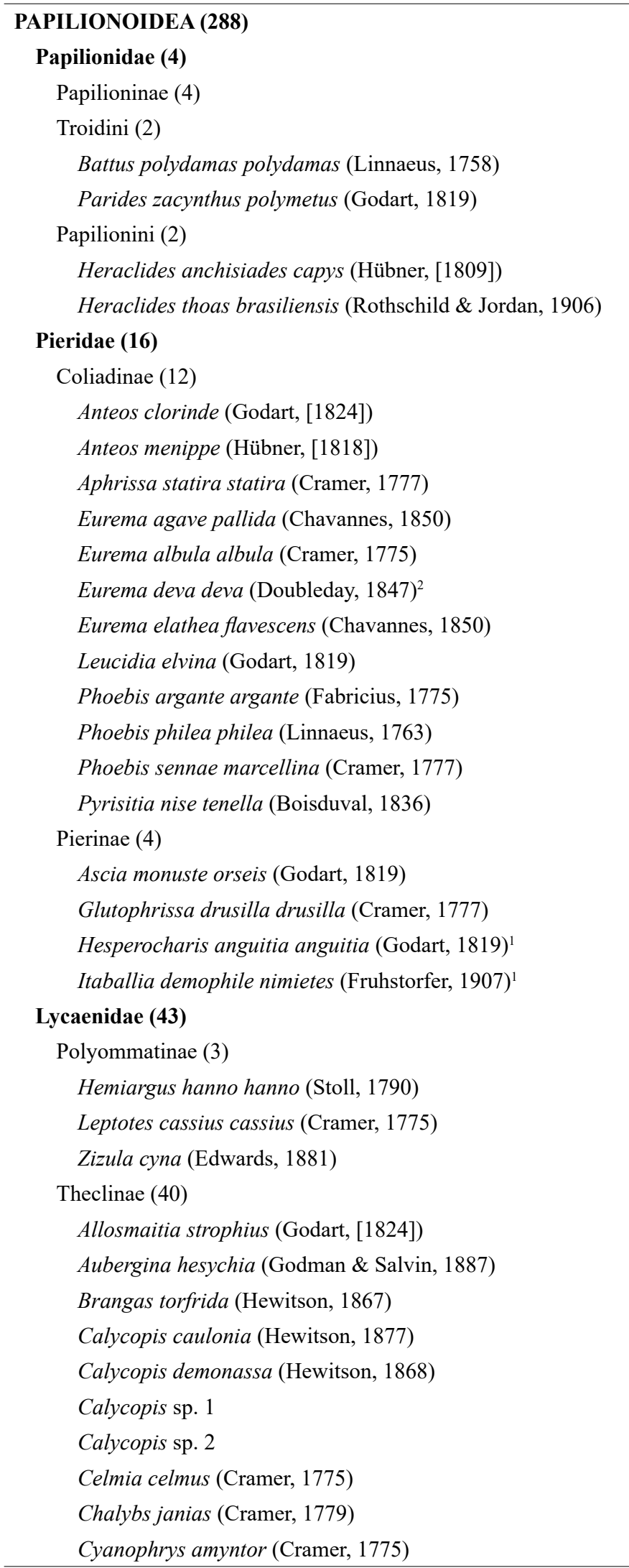

Continuation Table 1.

Gargina emessa (Hewitson, 1867)

Gargina sp.

Kisutam syllis (Godman \& Salvin, 1887)

Magnastigma hirsuta (Prittwitz, 1865)

Michaelus jebus (Godart, [1824])

Michaelus phoenissa (Hewitson, 1867)

Ministrymon cleon (Frabricius, 1775)

Ministrymon una (Hewitson, 1873)

Ministrymon zilda (Hewitson, 1873)

Nesiostrymon hyccara (Hewitson, 1868)

Nicolaea ophia (Hewitson, 1868)

Oenomaus sp.

Ostrinotes tarena (Hewitson, 1874)

Panthiades hebraeus (Hewitson, 1867)

Pseudolycaena marsyas (Linnaeus, 1758)

Rekoa palegon (Cramer, 1780)

Strephonota ambrax (Westwood, 1852)

Strymon astiocha (Prittwitz, 1865)

Strymon bubastus (Stoll, 1780)

Strymon mulucha (Hewitson, 1867)

Strymon ziba (Hewitson, 1868)

Symbiopsis sp.

Theclopsis gargara (Hewitson, 1868)

Thereus cithonius (Godart, [1824])

Thereus enenia (Hewitson, 1867)

Theritas hemon (Cramer, 1775)

Theritas triquetra (Hewitson, 1865)

Thestius lycabas (Cramer, 1777)

Tmolus echion (Linnaeus, 1767)

Ziegleria hesperitis (Butler \& H. Druce, 1872)

\section{Riodinidae (37)}

Nemeobiinae (1)

Euselasiini (1)

Euselasia cafusa (H. W. Bates, 1868)

Riodininae (36)

Eurybini (6)

Ionotus alector (Geyer, 1837)

Mesosemia nyctea lato Stichel, 1910

Perophthalma tullius (Fabricius, 1787)

Voltinia phryxe (C. Felder \& R. Felder, 1865)

Eurybia gonzaga Dolibaina, Dias, Mielke \& Casagrande, 2014

Eurybia halimede halimede (Hübner, [1807])

Riodinini (7)

Calephelis braziliensis McAlpine, 1971

Isapis agyrtus (Cramer, 1777)

Melanis smithiae (Westwood, 1851) 
Continuation Table 1.

Panara soana Hewitson, 1875

Pheles atricolor atricolor (Butler, 1871) 3

Rhetus arcius (Linnaeus, 1763)

Rhetus periander (Cramer, 1777)

Helicopini (3)

Anteros formosus formosus (Cramer, 1777)

Anteros renaldus (Stoll, 1790)

Sarota acanthoides (Herrich-Schäffer, [1853])

Nymphidiini (11)

Ariconias glaphyra (Westwood, 1851)

Parvospila lucianus (Fabricius, 1793)

Periplacis pretus (Cramer, 1777)

Nymphidium mantus (Cramer, 1775)

Nymphidium olinda H. W. Bates, 1865

Synargis calyce pernambuco Callaghan, 1999

Synargis gela (Hewitson, [1853])

Synargis paulistina (Stichel, 1910)

Roeberella lencates (Hewitson, 1875) ${ }^{3}$

Theope pieridoides C. Felder \& R. Felder, 1865

Theope sp.

Symmachiini (6)

Mesene florus (Fabricius, 1793)

Mesene monostigma monostigma (Erichson, [1849])

Mesene phareus (Cramer, 1777)

Mesene sp.

Panaropsis inaria (Westwood, 1851)

Pirascca sagaris satnius (Dalman, 1823)

Calydnini (3)

Calydna cea Hewitson, 1859

Calydna sturnula (Geyer, 1837)

Calydna sp.

\section{Nymphalidae (80)}

Nymphalinae (9)

Coeini (2)

Colobura dirce dirce (Linnaeus, 1758)

Historis odius dious Lamas, 1995

Nymphalini (1)

Vanessa myrinna (Doubleday, 1849) ${ }^{2}$

Kallimini (4)

Anartia amathea ssp.

Anartia jatrophae jatrophae (Linnaeus, 1763)

Junonia evarete evarete (Cramer, 1779)

Siproeta stelenes meridionalis (Fruhstorfer, 1909)

Melitaeini (2)

Anthanassa hermas hermas (Hewitson, 1864)

Tegosa sp.

\section{Continuation Table 1.}

Danainae (11)

Danaini (4)

Danaus eresimus plexaure (Godart, 1819) ${ }^{2}$

Danaus erippus (Cramer, 1775)

Danaus gilippus gilippus (Cramer, 1775)

Lycorea halia discreta Haensch, 1909

Ithomiini (7)

Dircenna dero celtina Burmeister, 1878

Episcada striposis Haensch, 1909

Hypothyris euclea laphria (Doubleday, 1847)

Hypothyris ninonia daetina (Weymer, 1899)

Mechanitis lysimnia nesaea Hübner, [1820]

Napeogenes inachia ssp.

Scada reckia reckia (Hübner, [1808])

Biblidinae (11)

Biblis hyperia nectanabis (Fruhstorfer, 1909)

Callicore astarte codomannus (Frabicius, 1781)

Callicore sorana sorana (Godart, [1824]) ${ }^{2}$

Dynamine athemon athemaena (Hübner, [1824])

Dynamine postverta postverta (Cramer, 1779)

Ectima thecla thecla (Fabricius, 1796)

Hamadryas amphinome amphinome (Linnaeus, 1767)

Hamadryas chloe rhea (Fruhstorfer, 1907) ${ }^{2}$

Hamadryas februa februa (Hübner, [1823])

Hamadryas feronia feronia (Linnaeus, 1758)

Pyrrhogyra neaerea susarion Fruhstorfer, $1912^{2}$

Cyrestinae (2)

Marpesia chiron marius (Cramer, 1779)

Marpesia petreus petreus (Cramer, 1776)

Satyrinae (29)

Morphini (1)

Morpho helenor anakreon Fruhstorfer, 1910

Brassolini (9)

Brassolis sophorae dinizi D’Almeida, 1956

Caligo brasiliensis brasiliensis (C. Felder, 1862)

Caligo illioneus illioneus (Cramer, 1775)

Caligo teucer ssp.

Dynastor darius darius (Fabricius, 1775)

Eryphanis automedon amphimedon (C. Felder \& R. Felder, 1867)

Opsiphanes cassiae crameri C. Felder \& R. Felder, 1862

Opsiphanes invirae remoliatus Fruhstorfer, 1907

Opsiphanes quiteria meridionalis (Staudinger, 1887)

Haeterini (2)

Pierella hyalinus ssp.

Pierella kesselringi Zacca, Siewert \& Paluch, 2016 
Melo, D.H.A. et al.

Continuation Table 1.

\section{Satyrini (17)}

Chloreuptychia chlorimene (Hübner, [1819])2

Cissia myncea (Cramer, 1780)

Cissia terrestris (Butler, 1867) ${ }^{1}$

Hermeuptychia atalanta (Butler, 1867)

Hermeuptychia gisella (Hayward, 1957)

Hermeuptychia hermes (Fabricius, 1775)

Magneuptychia libye (Linnaeus, 1767)

Pareuptychia sp.

Paryphthimoides sylvina (C. Felder \& R. Felder, 1867)

Taygetis echo echo (Cramer, 1775)

Taygetis laches laches (Fabricius, 1793)

Taygetis rufomarginata Staudinger, 1888

Taygetis sosis Hopffer, 1874

Taygetis virgilia (Cramer, 1776)

Yphthimoides affinis (Butler, 1867)

Yphthimoides renata (Stoll, 1780)

Zischkaia saundersii (Butler, 1867)

Limenitidinae (2)

Adelpha cytherea aea (C. Felder \& R. Felder, 1867)

Adelpha iphicleola leucates Fruhstorfer, 1915²

Charaxinae (6)

Anaeini (3)

Fountainea ryphea phidile (Geyer, 1837)

Hypna clytemnestra forbesi Godman \& Salvin, [1884]

Zaretis strigosus (Gmelin, 1790)

Preponini (3)

Archaeoprepona demophon thalpius (Hübner, [1814])

Archaeoprepona demophoon antimache (Hübner, [1819])

Prepona laertes laertes (Hübner, [1811])

Heliconiinae (10)

Argynnini (1)

Euptoieta hegesia meridiana Stichel, 1938

Heliconnini (9)

Agraulis vanillae maculosa (Stichel, 1908)

Dione juno juno (Cramer, 1779)

Dryadula phaetusa (Linnaeus, 1758)

Dryas iulia alcionea (Cramer, 1779)

Eueides isabella dianasa (Hübner, 1806)

Heliconius erato phyllis (Fabricius, 1775)

Heliconius ethilla flavomaculatus Weymer, 1894

Heliconius melpomene nanna Stichel, 1899

Heliconius sara apseudes (Hübner, 1806)

\section{Hesperiidae (108)}

Eudaminae (29)

Aguna megaeles megaeles (Mabille, 1988)

Astraptes alardus alardus (Stoll, 1790)
Continuation Table 1.

Astraptes anaphus anaphus (Cramer, 1777)

Astraptes fulgerator fulgerator (Walch, 1775)

Astraptes talus (Cramer, 1777)

Augiades crinisus (Cramer, 1780)

Autochton itylus Hübner, [1823]

Autochton neis (Geyer, 1832)

Autochton zarex (Hübner, 1818)

Bungalotis astylos (Cramer, 1780)

Bungalotis erythus (Cramer, 1775)

Bungalotis quadratum barba Evans, 1952

Chioides catillus catillus (Cramer, 1779)

Entheus priassus pralina Evans, 1952

Epargyreus exadeus exadeus (Cramer, 1779)

Narcosius colossus granadensis (Möschler, 1879)

Nascus phocus (Cramer, 1777)

Phanus australis L. D. Miller, 1965

Phanus marshalli (W. F. Kirby, 1880) ${ }^{2}$

Phocides polybius phanias (Burmeister, 1880) ${ }^{2}$

Pseudonascus paulliniae (Sepp, [1849])

Salatis salatis (Stoll, 1782)

Typhedanus undulatus (Hewitson, 1867) ${ }^{2}$

Urbanus dorantes (Stoll, 1790)

Urbanus procne (Plötz, 1880)

Urbanus proteus proteus (Linnaeus, 1758)

Urbanus teleus (Hübner, 1821)

Urbanus simplicius (Stoll, 1790)

Urbanus velinus (Plötz, 1880)

Pyrginae (22)

Anastrus neaeris narva Evans, 1953

Anastrus sempiternus simplicior (Möschler, 1877)

Camptopleura auxo (Möschler, 1879)

Gesta gesta (Herrich-Schäffer, 1863)

Gorgythion begga begga (Prittwitz, 1868)

Gorgythion sp.

Helias phalaenoides palpalis (Latreille, [1824])

Heliopetes alana (Reakirt, 1868)

Heliopetes arsalte (Linnaeus, 1758)

Morvina morvus morvus (Plötz, 1884)

Mylon cristata Austin, 2000

Nisoniades macarius (Herrich-Schäffer, 1870)

Pachyneuria sp.

Pyrgus orcus (Stoll, 1780)

Pyrgus veturius Plötz, 1884

Pyrrhopyge amythaon amythaon Bell, 1931

Quadrus cerialis (Stoll, 1782)

Staphylus perna Evans, 1953

Telemiades antiope tosca Evans, 1953 
Continuation Table 1.

\section{Telemiades $\mathrm{sp}$.}

Timochares trifasciata trifasciata (Hewitson, 1868)

Xenophanes tryxus (Stoll, 1780)

Hesperiinae (57)

Anthoptus epictetus (Fabricius, 1793)

Argon lota (Hewitson, 1877)

Arita arita (Schaus, 1902)

Callimormus alsimo (Möschler, 1883)

Callimormus corades (C. Felder, 1862)

Callimormus corus Bell, 1941

Callimormus radiola radiola (Mabille, 1878)

Calpodes ethlius (Stoll, 1782)

Cobalopsis miaba (Schaus, 1902)

Cobalopsis nero (Herrich-Schäffer, 1869)

Cobalus virbius hanta Evans, 1955

Corticea corticea (Plötz, 1882)

Corticea graziellae Bell, 1959

Cymaenes alumna (Butler, 1877)

Cymaenes tripunctus theogenis (Capronnier, 1874)

Cynea diluta (Herrich-Schäffer, 1869)

Cynea irma (Möschler, 1879)

Decinea lucifer (Hübner, [1831])

Flaccilla aecas (Stoll, 1781)

Hesperiinae sp. 1

Hesperiinae sp. 2

Hylephila phyleus phyleus (Drury, 1773)

Justinia justinianus justinianus (Latreille, [1824])

Methionsopis ina (Plötz, 1882)

Morys compta compta (Butler, 1877)

Morys sinta Evans, 1955

Mucia zygia (Plötz, 1886)

Naevolus orius orius (Mabille, 1883)

Niconiades nikko Hayward, 1948

Nyctelius nyctelius nyctelius (Latreille, [1824])

Onophas columbaria distigma Bell, 1930

Panoquina hecebolus (Scudder, 1872)

Panoquina lucas lucas (Fabricius, 1793)

Paracarystus hypargyra (Herrich-Schäffer, 1869)

Perichares philetes adela (Hewitson, 1867)

Phanes almoda (Hewitson, 1866)

Polites vibex catilina (Plötz, 1886)

Pompeius amblyspila (Mabille, 1898)

Pompeius pompeius (Latreille, [1824])

Quinta cannae (Herrich-Schäffer, 1869)

Remella remus (Fabricius, 1798)

Saliana esperi Evans, 1955

Saliana sp. 1

\section{Continuation Table 1.}

Saliana sp. 2

Saturnus metonidia (Schaus, 1902)

Synapte malitiosa equa Evans, 1955

Talides sergestus (Cramer, 1775) ${ }^{2}$

Talides alternata Bell, 1941

Thracides phidon (Cramer, 1779)

Vacerra bonfilius bonfilius (Latreille, [1824])

Vacerra sp.

Virga paraiba Nicolay, 1973

Vehilius celeus vetus Mielke, 1969

Vehilius stictomenes stictomenes (Butler, 1877)

Vettius artona (Hewitson, 1868)

Vettius marcus marcus (Fabricius, 1787)

Wallengrenia premnas (Wallengren, 1860)

\section{Discussion}

\section{Species richness}

The 288 butterfly species recorded at PEDI is considerably lower than at sites in SE Brazil (800+ species, Francini et al. 2011) and the Amazon Basin (up to 1700 species in Robbins et al. 1996 and Brown 2005), but is similar in richness to other inventories for the Atlantic Forest of northeastern Brazil. Kesselring \& Ebert (1982) found 291 butterfly species in the urban park "Mata do Buraquinho" in João Pessoa, Paraíba after five years of sampling. Paluch et al. $(2011,2016)$ recorded 197 species in a forest area in Caruaru, Pernambuco (216 sampling hours) and 260 species in Itanagra, Bahia (288 sampling hours), respectively. Cardoso (1949) recorded 218 butterfly species in the forest of Maceió, Alagoas after many years of sampling. Even though PEDI is located in an urban area of Recife that is close to a large highway, its butterfly fauna is comparable in richness to these other sites in northeastern Brazil.

The richness of Nymphalidae at PEDI was similar to that recorded in Kesselring \& Ebert (1982) and in other studies in the region (Cardoso 1949, Paluch et al. 2011, 2016). With seven species recorded, the number of Ithomiini is similar to that recorded in João Pessoa, Paraíba, with eight species (Kesselring \& Ebert 1982) and in Itanagra, Bahia, with seven species (Paluch et al. 2016). In contrast, 11 species of Ithomiini were recorded in Maceió, Alagoas (Cardoso 1949), 11 in Areia, Paraíba (see Kerpel et al. 2014), 14 in Caruaru, Pernambuco (Paluch et al. 2011), 17 in Usina Serra Grande, São José da Lage, Alagoas and 18 in the RPPN Frei Caneca, Jaqueira, Pernambuco (DHAM, Carlos E. B. Nobre and AVLF unpublished data), all sites in northeastern Brazil. PEDI lacks typical forest species such as Aeria olena ssp., Hypoleria alema oreas Weymer, 1899 and Heterosais edessa (Hewitson, [1855]), species recorded in some sites in the region (DHAM and AVLF pers, obs.). Further expeditions to the large area of "Fazenda Brejo dos Macacos" could add more species of Ithomiini associated with shaded humid forests.

The richness of Hesperiidae and Lycaenidae in PEDI was similar to that recorded by Kesselring \& Ebert (1982), but higher than other localities in the region (Cardoso 1949, Paluch et al. 2011, 2016). For 
Pieridae, the number of recorded species is similar to most inventories conducted in the region (Cardoso 1949, Kesselring \& Ebert 1982, Paluch et al. 2011, 2016). The richness of Papilionidae is low compared to that in southern Atlantic Forest sites (see Brown Jr. \& Freitas 2000), though similar to other well-sampled sites on the Atlantic Forest of northeastern Brazil (Kesselring \& Ebert 1982, Paluch et al. 2011, 2016). Finally, the number of Riodinidae species was similar to those in Kesselring \& Ebert (1982) and Paluch et al. (2016), but was greater than the numbers reported in Cardoso (1949) and Paluch et al. (2011).

\section{Taxonomic composition}

The relative contribution of each butterfly family in PEDI mirrors the pattern reported in the list of Brazilian butterflies and in all well sampled sites in Brazil. Hesperiidae is the richest family, followed by Nymphalidae (Brown Jr. \& Freitas 1999, 2000, Francini et al. 2011). Lycaenidae and Riodinidae are equivalent in richness in PEDI, a pattern similar to that observed in most southern Atlantic Forest sites and in montane forests. However, it diverges from that observed in the lowland forests of Rio de Janeiro and Espírito Santo (Brown Jr. \& Freitas 2000, Francini et al. 2011), where Riodinidae surpasses Lycaenidae. Clearly, additional surveys in other sites in the Pernambuco Center of Endemism and in the forests of Bahia are needed to better document these patterns.

In the Atlantic Forest, Nymphalidae is considered a reliable surrogate of the total butterfly fauna, generally making up $25-29 \%$ of the total butterfly fauna (Brown Jr. \& Freitas 2000). Based on this indicator, the fauna of PEDI would be expected to vary between 276 and 320 species, which is consistent with the 288 recorded species.

\section{Habitat}

The fauna of PEDI is dominated by species commonly found along forest edges, in open habitats and disturbed forests. As an example, all species of Pieridae recorded in the study site are typical of secondary forests and disturbed areas with the possible exception of Leucidia elvina (Godart, 1819). The same is true for Hesperiidae and Papilionidae, except for Parides zacynthus polymetus (Godart, 1819), and the major groups of Nymphalidae. The tribe Ithomiini (Nymphalidae: Danainae) is poorly represented, as noted, with most of those in PEDI associated with open disturbed habitats and forest edges (with the exception of Napeogenes inachia ssp.).

\section{Biogeography}

The biogeographic composition of the PEDI fauna shows a large contribution of widely distributed species, as illustrated with the Lycaenidae, Papilionidae and Pieridae. For Lycaenidae for example, many of the species have wide geographic distributions; with 24 of 43 species (56\%) occurring from Central America to Brazil. Alternately, some species are primarily Amazonian and penetrate the Atlantic Forest only in the north. Examples are Nesiostrymon hyccara (Hewitson, 1868), Ostrinotes tarena (Hewitson, 1874), and Thereus enenia (Hewitson, 1867). Others are endemic to the Atlantic Forest, such as Panthiades hebraeus (Hewitson, 1867) and Theritas triquetra (Hewitson, 1865). Although none of the Lycaenidae, Pieridae and Papilionidae at PEDI are endemic to the Pernambuco Center of Endemism, this is not true for Riodinidae. For example, the recently described Eurybia gonzaga is known only from Pernambuco (Dolibaina et al. 2014). It was also recorded in "RPPN Frei Caneca", Jaqueira (as type material, see
Dolibaina et al. 2014), in "Parque Natural Municipal Professor João Vasconcelos Sobrinho", Caruaru (cited as Eurybia pergaea by Paluch et al. 2011), and in "Estação Ecológica do Tapacurá", São Lourenço da Mata (DHAM pers, obs.). All sites are in Pernambuco, indicating that this species is a common faunistic component of this region. The Nymphalidae also present several taxa endemic or predominantly occurring in the Pernambuco Center of Endemism, such as Napeogenes inachia ssp. and Hypothyris ninonia daetina (Danainae: Ithomiini), Pierella hyalinus ssp. and Pierella kesselringi Zacca, Siewert \& Paluch, 2016 (Satyrinae: Haeterini), Morpho helenor anakreon Fruhstorfer, 1910 (Satyrinae: Morphini) and Heliconius ethilla flavomaculatus Weymer, 1894 (Heliconinae).

\section{Conservation}

No threatened butterflies are recorded in PEDI, but there is a historical record (about 50 years ago) of Morpho menelaus eberti Fischer, 1962 (Nymphalidae: Satyrinae: Morphini) in the "Chapéu do Sol", deposited in the National Museum of Natural History in Paris (Blandin 2007). Although habitat loss, years of logging and other urban related disturbances could explain the local extinction of M. melenaus eberti, this butterfly could still persist in the area in low densities. Another threatened morphine that could be present in the area is Morpho epistrophus nikolajewna Weber, 1951. This butterfly has been recorded to the south in Maceió (Cardoso 1949), to the north in Igarassu (Carlos E. B. Nobre pers. comm.) and in João Pessoa (Kesselring \& Ebert 1982), which are Atlantic Forest fragments near urban areas. Further sampling is needed before stating that both species of Morpho Fabricius, 1807 are absent in forested areas around Recife.

The reported results showed that PEDI possesses a relatively rich butterfly community. Considering the degree of threat to the fauna of the Atlantic Forest of northeastern Brazil, PEDI is of enormous importance for conserving butterflies, as it is for vertebrates such as birds and mammals (Machado et al. 1998). Conservation strategies should be developed in conjunction with public entities, such as the Environment Secretariat of Recife, and non-governmental organizations such as the "Centro de Pesquisas Ambientais do Nordeste" (CEPAN), and with the local communities surrounding the whole area. Priority actions for PEDI should include the proposition of a sustainable management plan focused on reintroduction of locally extinct species of plants and animals, an effective plan for restoring heavily disturbed areas, and establishment of programs of ecological monitoring and management of the surrounding environments so that the area can persist as an important Atlantic Forest remnant.

\section{Acknowledgements}

We are indebted to all the staff of the "Parque Estadual Dois Irmãos" by allowing research in the area. We also thank David Douglas for their assistance in the field activities and Silvino Pinto for the photographs of butterflies provided for consultation. The following people helped with identifications: Curtis Callaghan (Riodinidae) and Noemy Seraphim (Hermeuptychia). We also are grateful to the ICMBio for the research permits (SISBIO $n^{\circ} 10802-5$ ). AVLF thanks the CNPq (process 302585/2011-7), the BR-BoL (MCT/CNPq/FNDCT 50/2010), the FAPESP (grant 2012/50260-6) and the National Science Foundation (DEB-1256742). OHHM thanks the CNPq for the fellowship (process 
304639/2014-1). MD thanks CNPq (process 305905/2012-0), FAPESP (process 2012/13898-0) and Pró-Reitoria de Pesquisa da Universidade de São Paulo (Projeto 1). This publication is part of the RedeLep 'Rede Nacional de Pesquisa e Conservação de Lepidópteros' SISBIOTABrasil/CNPq (563332/2010-7), and of the BIOTA-FAPESP Program (2011/50225-3).

\section{Author Contribution}

Douglas H. A. Melo: contributed in the concept and design of the study, data collection, data analysis and interpretation, and in the manuscript preparation.

Marcelo Duarte: contributed in the data analysis and interpretation, and in the critical revision, adding intelectual content.

OlafH. H. Mielke: contributed in the data analysis and interpretation, and in the critical revision, adding intelectual content.

Robert K. Robbins: contributed in the data analysis and interpretation, and in the critical revision, adding intelectual content.

André V. L. Freitas: contributed in the concept and design of the study, data collection, data analysis and interpretation, manuscript preparation, and in the critical revision, adding intelectual content.

\section{Conflicts of Interest}

The authors declare that they have no conflict of interest related to the publication of this manuscript.

\section{References}

ALVARES, C.A., STAPE, J.L., SENTELHAS, P.C., GONÇALVES, J.L.M \& SPAROVEK, G. 2014. Köppen's climate classification map for Brazil. Meteorol. Z. 22(6):711-728.

BATES, H.M. 1867. On a collection of butterflies formed by Thomas Belt, ESQ., in the interior of the province of Maranham, Brazil. Trans. Entomol. Soc. London 15(7):535-546.

BLANDIN, P. 2007. The systematics of the genus Morpho, Fabricius, 1807 (Lepidoptera Nymphalidae, Morphinae). Hillside Books, Canterbury.

BROWN JR., K.S. 1972. Maximizing daily butterfly counts. J. Lepid. Soc. 26(3):183-196.

BROWN JR., K.S. 1977. Centros de evolução, refúgios quaternários e conservação de patrimônios genéticos na região neotropical: padrões de diferenciação em Ithomiinae (Lepidoptera: Nymphalidae). Acta Amaz. 7(1):75-137.

BROWN JR, K.S. 2005. Geological, evolutionary and ecological bases of the diversification of Neotropical butterflies: implications for conservation. In Tropical rainforests: Past, Present and Future (E. Bermingham, C.W. Dick \& C. Moritz, eds). University of Chicago Press, Chicago, p.166-201.

BROWN JR., K.S. \& FREITAS, A.V.L. 1999. Lepidoptera. In Biodiversidade do Estado de São Paulo, Brasil: invertebrados terrestres (C.R.F. Brandão \& E.M. Cancello, eds). FAPESP, São Paulo, p.225-245.

BROWN JR., K.S. \& FREITAS, A.V.L. 2000. Atlantic Forest butterflies: indicators for landscape conservation. Biotropica 32(4b):934-956.

CALLAGHAN, C.J. \& NOBRE, C.E.B. 2014. A new species of Pheles Herrich-Schaeffer from Northeast Brazil (Lepidoptera, Riodinidae). Zootaxa 3780(3):558-566.

CARDOSO, A. 1949. Lepidópteros de Alagoas. Rev. Entomol. 20(1-3):427-436.

CARDOSO, M.Z. 2005. New localities for Heliconius besckei Ménétriés and Heliconius sara (Fabricius) (Lepidoptera, Nymphalidae) in Bahia, Brazil. Neotrop. Entomol. 34(6):1007-1008.
COUTINHO, R.Q., LIMA-FILHO, M.F., SOUZA-NETO, J.B. \& SILVA, E.P. 1998. Características climáticas, geológicas, geomorfológicas, e geotécnicas da Reserva Ecológica de Dois Irmãos. In Reserva ecológica de Dois Irmãos: estudos em um remanescente de Mata Atlântica em área urbana (Recife - Pernambuco - Brasil) (I.C. Machado, A.V. Lopes \& K.C. Pôrto, orgs). Secretaria de Ciências, Tecnologia e Meio Ambiente - SECTMA, Ed. Universitária da UFPE, Recife, p.21-49.

D’ALMEIDA, R. F. 1935. Lista dos lepidópteros capturados pelo Dr. R.V. Ihering no Nordeste do Brasil. Rev. Entomol. 5(3):326-328.

DOLIBAINA, D.R., DIAS, F.M.S., MIELKE, O.H.H. \& CASAGRANDE, M.M. 2014. A new species of Eurybia (Lepidoptera: Riodinidae: Eurybiini) from northeastern Brazil. Fla. Entomol. 97(3):1208-1212.

DUARTE JÚNIOR, J.A., ROBERTO, F.A.S., FRANÇA, B.R.A. \& MAGGI, B. 2001. Levantamento Preliminar dos Lepidoptera (Papilionoidea Hesperioidea) do Parque Estadual Dunas, Natal, Rio Grande do Norte, Brasil. Entomol. Vectores 8(3):365-369.

FRANCINI, R.B., DUARTE, M., MIELKE, O.H.H., CALDAS, A. \& FREITAS, A.V.L. 2011. Butterflies (Lepidoptera, Papilionoidea and Hesperioidea) of the "Baixada Santista" region, coastal São Paulo, southeastern Brazil. Rev. Bras. Entomol. 55(1):55-68.

FREITAS, A.V.L. \& BROWN JR., K.S. 2005. Immature stages of Napeogenes sulphurina Bates, 1862 (Lepidoptera, Nymphalidae, Ithomiinae) from Northeastern Brazil. J. Lepid. Soc. 59(1):35-37.

FREITAS, A.V.L. \& MARINI-FILHO, O.J. 2011. Plano de ação nacional para a conservação dos lepidópteros ameaçados de extinção. Instituto Chico Mendes de Conservação da Biodiversidade (ICMBio)

HALL, J.P.W. 2018. A Monograph of the Nymphidiina (Lepidoptera: Riodinidae: Nymphidiini): Phylogeny, Taxonomy, Biology, and Biogeography. Entomological Society of Washington, Washington, DC

HEIKKILÄ, M., KAILA, L., MUTANEN, M., PEÑA, C. \& WAHLBERG, N. 2012. Cretaceous origin and repeated tertiary diversification of the redefined butterflies. Proc. R. Soc. B 279(1731): 1093-1099.

ISERHARD, C.A., BROWN JR., K.S. \& FREITAS, A.V.L. 2013. Maximized sampling of butterflies to detect temporal changes in tropical communities. J. Insect. Conserv. 17(3):615-622.

ISERHARD, C.A., UEHARA-PRADO, M., MARINI-FILHO, O.J., DUARTE, M. \& FREITAS, A.V.L. 2017. Fauna da Mata Atlântica: Lepidoptera Borboletas. In Revisões em Zoologia - Fauna da Mata Atlântica (E.L.A. Monteiro \& C.E. Conte, orgs). Editora da UFPR, Curitiba, Paraná, p.57-102; 496-499 (color plates).

KERPEL, S.M., FERREIRA JR, A. \& FREITAS, A.V.L. 2014. New record of the endangered Brazilian swallowtail Heraclides himeros baia (Rothschild \& Jordan, 1906). J. Lepid. Soc. 68(2):145-146.

KERPEL, S., ZACCA, T., NOBRE, C.E.B., JUNIOR, A.F., XAVIER, M. \& FONSECA, A. 2014. Borboletas do Semiárido, conhecimento atual e contribuições do PPBio. In Artrópodes do Semi-Árido: biodiversidade e conservação (F. Bravo \& A.R. Calor, eds). Printmídia, Feira de Santana p.245-275.

KESSELRING, J. \& EBERT, H. 1979 [1982]. Relação das borboletas encontradas na "Mata do Buraquinho", João Pessoa, estado da Paraíba, Brasil. Rev. Nordest. Biol. 2(1):105-108.

LAMAS, G. 2004. Checklist: Part 4A Hesperioidea - Papilionoidea. In Atlas of Neotropical Lepidoptera (J.B. Heppner, ed.) Association of Tropical Lepidoptera, Gainesville.

LIMA, J.N.R. \& ZACCA, T. 2014. Lista de espécies de borboletas (Lepidoptera: Hesperioidea e Papilionoidea) de uma área de semiárido na região nordeste do Brasil. EntomoBrasilis 7(1):33-40.

MACHADO, I.C., LOPES, A.V. \& PÔRTO, K.C. 1998. Reserva Ecológica de Dois Irmãos: Estudos em um remanescente de Mata Atlântica em área urbana (Recife - Pernambuco - Brasil). Secretaria de Ciência e Tecnologia e Meio Ambiente - SECTMA - UFPE, Recife.

MELO, D.H.A., FILGUEIRAS, B.K.C., LEAL, I.R. \& FREITAS, A.V.L. 2014. Recent records of Morpho menelaus eberti (Fischer) (Lepidoptera: Nymphalidae), an endangered butterfly in Northeast Brazil. Trop. Lepid. Res. 24(2):102-104. 
NOBRE, C.E.B., SCHLINDWEIN, C. \& MIELKE, O.H.H. 2008. The butterflies (Lepidoptera: Papilionoidea and Hesperioidea) of the Catimbau National Park, Pernambuco, Brazil. Zootaxa 1751:35-45.

NOBRE, C.E.B. \& SCHLINDWEIN, C. 2011. New records for species of Theope (Lepidoptera, Riodinidae) for the state of Pernambuco and northeastern Brazil, with notes on their natural history. Rev. Bras. Entomol. 55(2):275278.

NOBRE, C.E.B., IANNUZZI, L. \& SCHLINDWEIN, C. 2012. Seasonality of Fruit-Feeding Butterflies (Lepidoptera, Nymphalidae) in a Brazilian Semiarid Area. ISRN Zoology 2012:1-8.

NOBRE, C.E.B. \& SCHLINDWEIN, C. 2012. New records of Heraclides a astyalus (Godart) (Lepidoptera: Papilionini) on the northern São Francisco river, Brazil. CheckList 8(5):927-928.

NOBRE, C.E.B. \& ROBBINS, R.K. 2014. Arawacus euptychia (Lepidoptera: Lycaenidae: Eumaeini) is no longer an obscure species. J. Res. Lepid. 47:73-78.

PALUCH, M., MIELKE, O.H.H., LINHARES, L.M. \& SILVA, D.C. 2016. Butterflies (Lepidoptera: Papilionoidea and Hesperioidea) of the Private Reserve of Natural Heritage Fazenda Lontra/Saudade, Itanagra, Northern Coast of Bahia, Brazil. Biota Neotrop. 16(1): e20140085. http://dx.doi. org/10.1590/1676-0611-BN-2014-0085.

PALUCH, M., MIELKE, O.H.H., NOBRE, C.E.B., CASAGRANDE, M.M., MELO, D.H.A. \& FREITAS, A.V.L. 2011. Butterflies (Lepidoptera: Papilionoidea and Hesperioidea) of the Parque Ecológico João Vasconcelos Sobrinho, Caruaru, Pernambuco, Brazil. Biota Neotrop. 11(4):229238. http://www.biotaneotropica.org.br/v11n4/pt/abstract?inventory + bn01911042011.

RANTA, P., BLOM, T., NIEMELA, J., JOENSUU, E. \& SIITIONEN, M. 1998 The fragmented Atlantic rain forest of Brazil: size, shape and distribution of forest fragments. Biodivers. Conserv. 7(3):385-403.

RIBEIRO, M.C., METZGER, J.P., MARTENSEN, A.C., PONZONI, F.J. \& HIROTA, M.M. 2009. The Brazilian Atlantic Forest: how much is left, and how is the remaining forest distributed? Implications for conservation. Biol. Conserv. 142(6):1141-1153.
ROBBINS, R.K., LAMAS, G., MIELKE, O.H.H., HARVEY, D.J. \& CASAGRANDE, M.M. 1996. Taxonomic composition and ecological structure of the species-rich butterfly community at Pakitza, Parque Nacional del Manu, Perú. In The biodiversity of southeastern Peru (D.E. Wilson \& A. Sandoval eds). Smithsonian Institution, Washington, DC, p.217-252.

SANTOS, A.M.M., CAVALCANTI, D.R., SILVA, J.M.C. \& TABARELLI, M. 2007. Biogeographical relationships among tropical forests in northeastern Brazil. J. Biogeogr. 34(3):437-446.

SANTOS, E.C., MIELKE, O.H.H. \& CASAGRANDE, M.M. 2008. Inventários de borboletas no Brasil: Estado da arte e modelo de áreas prioritárias para pesquisa com vista à conservação. Nat. Conserv. 6(2):68-90.

SERAPHIM, N., KAMINSKI, L.A., DeVRIES, P.J., PENZ, C., CALLAGHAN, C., WAHLBERG, N., SILVA-BRANDÃO, K.L. \& FREITAS, A.V.L. 2018 Molecular phylogeny and higher systematics of the metalmark butterflies (Lepidoptera: Riodinidae). Syst. Entomol. 43(2):407-425.

SILVA, A.G. 1967. Catálogo dos Lepidoptera Cearenses. Revi. Inst. Ceará 91-112.

VASCONCELOS, R.N., BARBOSA, E.C.C. \& PERES, M.C.L. 2009. Borboletas do Parque Metropolitano de Pituaçu, Salvador, Bahia, Brasil. Sitientibus. Ser. Cienc. Biol. 9(2/3):158-164.

VELOSO, H.P., RANGEL-FILHO, A.L. \& LIMA, J.C.A. 1991. Classificação da vegetação brasileira adaptada a um sistema universal. IBGE, Rio de Janeiro, Brazil.

ZACCA, T., BRAVO, F. \& XAVIER, M.X. 2011. Butterflies (Lepidoptera:Papilionoidea and Hesperioidea) from Serra da Jibóia, Bahia State, Brazil. EntomoBrasilis 4(3):139-143.

ZACCA, T. \& BRAVO, F. 2012. Borboletas (Lepidoptera: Papilionoidea e Hesperioidea) da porção norte da Chapada Diamantina, Bahia, Brasil. Biota Neotrop. 12(1): 117-126. http://www.biotaneotropica.org.br/v12n2/en/abst ract?inventory+bn00212022012

WAHLBERG, N., LENEVEU, J., KODANDARAMAIAH, U., PEÑA, C., NYLIN, S., FREITAS, A.V.L. \& BROWER, A.V.Z. 2009. Nymphalid butterflies diversify following near demise at the Cretaceous/Tertiary boundary. Proc. R. Soc. B 276(1677):4295-4302.

WARREN, A.D., OGAWA, J.R. \& BROWER, A.V.Z. 2009. Revised classification of the family Hesperiidae (Lepidoptera: Hesperioidea) based on combined molecular and morphological data. Syst. Entomol. 34(3):467-523.

Received: $04 / 08 / 2018$

Revised: 19/09/2018

Accepted: 30/11/2018

Published online: 10/01/2019 